\title{
Pancreatic damage control: the pancreas is simple don't complicate it
}

\section{El control de daños en el páncreas es simple. No complique las cosas}

I. OPEn Access

Citation: Ordoñez CA, Parra MW, Millán M. Caicedo Y, Padilla N, Guzmán RM, Millán AF, García A, González HA, Pino LF, Rodríguez HF, Serna JJ, Salcedo A, Ferrada $\mathrm{R}$, Ivatury R. Pancreatic damage control: the pancreas is simple don't complicate it. Colomb Med (Cali).2020; 51(4) e-4054361 http:// doi.org/10.25100/cm.v51i4.4361

Received : 01 Jul 2020

Revised : 14 Sep 2020

Accepted : 10 Oct 2020

Published: 07 Dec 2020

Keywords:

Pancreatic Damage Control; Suture; Drainage; Pancreatic Fistula; Pancreatectomy; Peritoneal Cavity; Amylases; Ampulla of Vater; Enteral Nutrition; Splenectomy; Negative-Pressure Wound Therapy; Critical Illness; Cholecystostomy; Operating Rooms; Laparotomy; Lacerations.

Palabras clave:

Control de daños pancreático; sutura; drenaje; fístula pancreática; pancreatectomía; cavidad peritoneal; amilasas; ampolla de vater; nutrición enteral; esplenectomía; terapia de heridas con presión negativa; enfermedad crítica; colesistectomía; quirófano; laparatomía; laceraciones.

\author{
Carlos A. Ordoñez ${ }^{1,2,3}$,Michael W. Parra ${ }^{6}$, Mauricio Millán ${ }^{3,5}$, ${ }^{6}$, Yaset Caicedo ${ }^{6}$ \\ Natalia Padilla ${ }^{6}$, Mónica Guzmán-Rodríguez ${ }^{7}$, Fernando Miñan-Arana ${ }^{8,9}{ }^{6}$, Alberto \\ García $^{1,2,10}$, Adolfo González-Hadad ${ }^{2,10,11}$, Luis Fernando Pino $0^{2,10}$, Fernando \\ Rodríguez-Holguin ${ }^{1,3}$, José Julián Serna ${ }^{1,2,3,10}$, Alexander Salcedo ${ }^{1,2,3,10}$, Ricardo \\ Ferrada $^{2,11}$, Rao Ivatury ${ }^{12}$ (D) \\ ordonezcarlosa@gmail.com, carlos.ordonez@fvi.org.co
}

1 Fundación Valle del Lili, Department of Surgery, Division of Trauma and Acute Care Surgery. Cali, Colombia. 2 Universidad del Valle, Department of Surgery, Division of Trauma and Acute Care Surgery. Cali, Colombia. 3 Universidad Icesi, Cali, Colombia. 4 Broward General Level I Trauma Center, Department of Trauma Critical Care, Fort Lauderdale, FL USA, 5 Fundación Valle del Lili, Department of Surgery, Division of Transplant Surgery, Cali, Colombia. 6 Fundación Valle del Lili, Centro de Investigaciones Clínicas (CIC), Cali, Colombia, 7 Universidad de Chile, Facultad de Medicina, Instituto de Ciencias Biomédicas, Santiago de Chile, Chile. 8 Universidad Espiritu Santo, Department of Surgery, Guayaquil, Ecuador. 9 Hospital Dr. Abel Gilbert Ponton, Department of Surgery, Division of Trauma and Acute Care Surgery, Guayaquil, Ecuador. 10 Hospital Universitario del Valle, Department of Surgery, Division of Trauma and Acute Care Surgery. Cali, Colombia. 11 Centro Médico Imbanaco, Cali, Colombia. 12 Professor Emeritus Virginia Commonwealth University, Richmond, VA, USA.

\section{Abstract}

Pancreatic trauma is a rare but potentially lethal injury because often it is associated with other abdominal organ or vascular injuries. Usually, it has a late clinical presentation which in turn complicates the management and overall prognosis. Due to the overall low prevalence of pancreatic injuries, there has been a significant lack of consensus among trauma surgeons worldwide on how to appropriately and efficiently diagnose and manage them. The accurate diagnosis of these injuries is difficult due to its anatomical location and the fact that signs of pancreatic damage are usually of delayed presentation. The current surgical trend has been moving towards organ preservation in order to avoid complications secondary to exocrine and endocrine function loss and/or potential implicit post-operative complications including leaks and fistulas. The aim of this paper is to propose a management algorithm of patients with pancreatic injuries via an expert consensus. Most pancreatic injuries can be managed with a combination of hemostatic maneuvers, pancreatic packing, parenchymal wound suturing and closed surgical drainage. Distal pancreatectomies with the inevitable loss of significant amounts of healthy pancreatic tissue must be avoided. General principles of damage control surgery must be applied when necessary followed by definitive surgical management when and only when appropriate physiological stabilization has been achieved. It is our experience that viable un-injured pancreatic tissue should be left alone when possible in all types of pancreatic injuries accompanied by adequate closed surgical drainage with the aim of preserving primary organ function and decreasing short and long term morbidity. 
Copyright: @ 2020 Universidad del Valle.

(c) $(1)$

Conflict of Interest:

The authors declare not to have any conflict of interest

\section{Acknowledgment:}

Dedicated to Dr. Edilberto Gómez, (1946-1997). Professor of Surgery at the Universidad del Valle - Colombia. Pioneer in the management of pancreatic trauma with the preservation of its parenchyma, avoiding radical resections and performing primary suture.

For the illustrations and the design of the cover to the Anatomical Draftsman Fabian R. Cabrera P. Professor of the Design Department of the Faculty of Integrated Arts of the Universidad del Valle.

Corresponding author:

Carlos A. Ordonez, MD, FACS.

Division of Trauma and Acute Care

Surgery, Department of Surgery.

Fundación Valle del Lili. Cali, Colombia;

Division of Trauma and Acute Care

Surgery, Department of Surgery,

Universidad del Valle, Cali, Colombia;

Universidad Icesi, Cali, Colombia.

Email: ordonezcarlosa@gmail.com,

carlos.ordonez@fvi.org.co

\section{Resumen}

El trauma pancreático es un tipo de trauma poco común potencialmente fatal que está asociado con lesiones de órganos abdominales o vasculares. Usualmente, los signos clínicos son tardíos aumentado el riesgo de complicaciones respecto al manejo y al pronóstico general. Debido a la baja prevalencia de la lesión del trauma, no existe consenso entre los cirujanos alrededor del mundo sobre cómo se debe diagnosticar y tratar adecuadamente este desafío quirúrgico. La precisión en el diagnóstico es difícil por la localización anatómica y las manifestaciones clínicas tardías. El abordaje quirúrgico ha ido cambiando de dirección hacia la preservación del órgano para evitar complicaciones secundarias asociada a la perdida de la función exocrina y endocrina, o de potenciales complicaciones postquirúrgicas incluyendo las dehiscencias y fistulas. El objetivo de este artículo es proponer un algoritmo de manejo del trauma pancreático a través de un consenso de expertos. Las lesiones del páncreas pueden ser manejadas con una combinación de maniobras hemostáticas, empaquetamiento pancreático, sutura de la herida y drenaje quirúrgico cerrado. La pancreatectomía distal con la perdida de tejido vital pancreático debe ser evitadas. Los principios generales de la cirugía de control de daños deben ser aplicados cuando sea necesario para un manejo quirúrgico definitivo cuando y solo cuando la estabilización fisiológica haya sido lograda. En nuestra experiencia, el tejido pancreático sano debe preservarse cuando el trauma se asocia de un manejo mediante un drenaje quirúrgico cerrado con el objetivo de preservar la función primaria del órgano y disminuir a corto y largo tiempo las morbilidades.

\section{Remark}

\section{1) Why was this study conducted?}

It is the initiative from Trauma and Emergency Surgery Group to consolidate the novel proposal regarding the pancreatic trauma management.

\section{2) What were the most relevant results of the study?}

Most pancreatic injuries can be managed with a combination of hemostatic maneuvers, pancreatic packing, parenchymal wound suturing, and closed surgical drainage.

\section{3) What do these results contribute?}

Pancreatic trauma treated by parenchymal wound suturing is the main strategy to preserve the primary organ function and decreasing short- and long-term morbidity. 


\section{Background}

Pancreatic trauma is a rare but potentially lethal injury because often it is associated with other abdominal organ or vascular injuries. Usually it has a late clinical presentation which in turn complicates the management and overall prognosis ${ }^{1}$. Due to the overall low prevalence of pancreatic injuries, there has been a significant lack of consensus among trauma surgeons worldwide on how to appropriately and efficiently diagnose and manage them ${ }^{2,3}$. But what is well known is that the surgical approach of these injuries depends if the pancreatic duct is involved or not ${ }^{3,4}$. The accurate diagnosis of these injuries is difficult due to its anatomical location and the fact that signs of pancreatic damage are usually of delayed presentation ${ }^{5,6}$. The classic management recommendations for AAST Grade III injury of the distal half of the pancreas has been a distal pancreatectomy and for AAST Grades IV and V injuries has been a formal pancreatic duodenectomy ${ }^{3,4}$. However, the current surgical trend has been moving towards organ preservation in order to avoid complications secondary to exocrine and endocrine function loss from partial or complete organ resection and/or potential implicit post-operative complications including leaks and fistulas ${ }^{7-9}$. The aim of this paper is to propose a management algorithm of patients with pancreatic injuries via an expert consensus.

This article is a consensus that synthesizes the experience earned during the past 30 years in trauma critical care management of the severely injured patient from the Trauma and Emergency Surgery Group (CTE) of Cali, Colombia which is made up of experts from the University Hospital Fundación Valle del Lili, the University Hospital del Valle "Evaristo García”, Universidad del Valle and Universidad Icesi, Colombian Association of Surgery, the Pan-American Trauma Society and the collaboration of international specialists of the United States of America.

\section{Epidemiology}

Pancreatic injuries account for approximately $0.2 \%$ of all trauma cases and $3 \%$ of all abdominal trauma cases. The most common worldwide mechanism is blunt trauma caused by road traffic accidents ${ }^{2}$. A multicenter nationwide cohort study in Japan from 2004 to 2017 found a total of 743 patients with pancreatic trauma (2.4\% of all abdominal trauma) and found that 337 (45.4\%) had AAST Grade I injury, 66 (8.9\%) Grade II, 178 (24.0\%) Grade III, 62 (8.3\%) Grade IV and 100 (13.5\%) Grade $\mathrm{V}^{10}$. Also, 52.5\% had concomitant severe associated injuries (liver $15.7 \%$ and vascular 15.5\%). Three hundred and five (41\%) received non-operative management, $70(9.4 \%)$ had partial resection of the pancreas and $31(4.1 \%)$ had Damage Control Surgery (DCS). The overall mortality was 14\%, and the variables associated with higher risk of death were: higher AAST Grade, increased age and the coexistence of severe injuries ${ }^{10}$. Data on pancreatic trauma in Latin-America is scarce, but what is evident is that in Cali, Colombia penetrating trauma is more frequent than in many other cities and/or countries. Our registry has shown that the incidence of penetrating pancreatic trauma is as common as blunt trauma and tends to be more severe and associated with other significant injuries. A retrospective review of our institutional experience on penetrating pancreatic trauma between 2000 and 2013 found a total of 28 patients, of which 26 were by gunshot wounds with a median anatomical severity given by the Penetrating Abdominal Trauma Index (PATI) of $50(\mathrm{IQR}=34.5-67.5)$ with a median of five associated injuries highlighting the complexity of these cases ${ }^{11}$. Of the 28 patients, $6(21.4 \%)$ had AAST Grade I injury, 9 (32\%) Grade II, 5 (18\%) Grade III, 5 (18\%) Grade IV and 3 (10\%) had Grade V injury. We found that the management of these penetrating injuries were different from prior published case series because $83 \%$ of our patients received DCS techniques, $12(42.9 \%)$ had simple suture repair of the pancreatic laceration, $8(28.6 \%)$ had a distal pancreatectomy and none of them underwent pancreatic duodenectomy ${ }^{12}$. 
Pancreatic damage control: the pancreas is simple don't complicate it

Table 1. The American Association for the Surgery of Trauma (AAST) classification of pancreatic injury 25.

\begin{tabular}{ll}
\hline Grade & Description \\
\hline I & Minor contusion without duct injury or superficial laceration without duct injury \\
II & Major contusion or laceration without duct injury or tissue lost \\
III & Distal transaction or parenchymal injury with duct injury \\
IV & Proximal (to right of the superior mesenteric vein) transaction or parenchymal injury with duct injury \\
V & Massive disruption of pancreatic head \\
\hline
\end{tabular}

\section{Initial approach and diagnosis}

Initial management must be directed towards the stabilization of the patient according to ATLS guidelines and following Damage Control Resuscitation (DCR) principles. Upon arrival, the choice between immediate surgical exploration or further imaging studies is dependent on the hemodynamic status of the patient. If the patient is hemodynamically stable or a transient responder, a Whole Body Computed Tomography (WBCT) should be performed to determine the extent of the pancreatic injury and any other significant findings. The hallmarks of pancreatic injury on Computed Tomography (CT) are peri-pancreatic hematoma, retroperitoneal edema and laceration of the body of the pancreas ${ }^{5,12}$. However, patients with peritoneal signs and/or hemodynamic instability (sustain systolic blood pressure (SBP) (90 $\mathrm{mmHg}$ ) should be transferred immediately to the operating room (OR) and the diagnosis of a pancreatic injury should be done during the initial exploratory laparotomy. Is important to note that opening of the lesser sac and direct detailed inspection of the pancreas is required to accurately stage the injury ${ }^{13,14}$ (Table 1).

\section{Surgical management}

During the initial exploratory laparotomy, the trauma surgeon should initially control all sources of ongoing surgical bleeding followed by control of sources of bowel contamination. Only then can he or she direct his or her attention to staging the involved pancreatic injury. If the patient develops hemodynamic instability during or prior to the procedure with a sustained SBP $(70 \mathrm{mmHg}$ or less, regardless of aggressive DCR, the placement of a Resuscitative Balloon Occlusion of the Aorta (REBOA) should be considered and placed in Zone I as an adjunct ${ }^{15,16}$. Although the management of specific lesions of the pancreas are controversial ${ }^{8}$, ranging from radical approaches such as a pancreatic duodenectomy in cases of AAST Grade V injuries ${ }^{17}$, it is our general recommendation to always seek preservation of pancreatic tissue, leaving resection as a last resort ${ }^{17}$. The appropriate staging of a pancreatic injury of the body and tail of the pancreas can be done via the lesser sac. An injury localized at the head or uncinate process will require both the lesser sac to be opened but also a formal Kocher Maneuver to adequately evaluate the pancreatic duodenal complex (Figure 1).

When facing a pancreatic injury, three anatomical landmarks must be clearly delineated:

- The Main Pancreatic Duct

- The Superior Mesenteric Vessels

- The Ampulla of Vater

All pancreatic injuries can then be appropriately classified according to the criteria of the American Association for the Surgery of Trauma (AAST). The surgical management of these injuries as per these grades is as follows:

- $\quad$ AAST Grade I: hemostasis and +/- surgical drainage

- $\quad$ AAST Grade II: simple hemostasis maneuvers, if bleeding does not stop, perform pancreatic laceration repair with non-absorbable monofilament 3-0 suture (interrupted or continuous depending on surgeon's preference) and surgical drainage (Figure 2). 


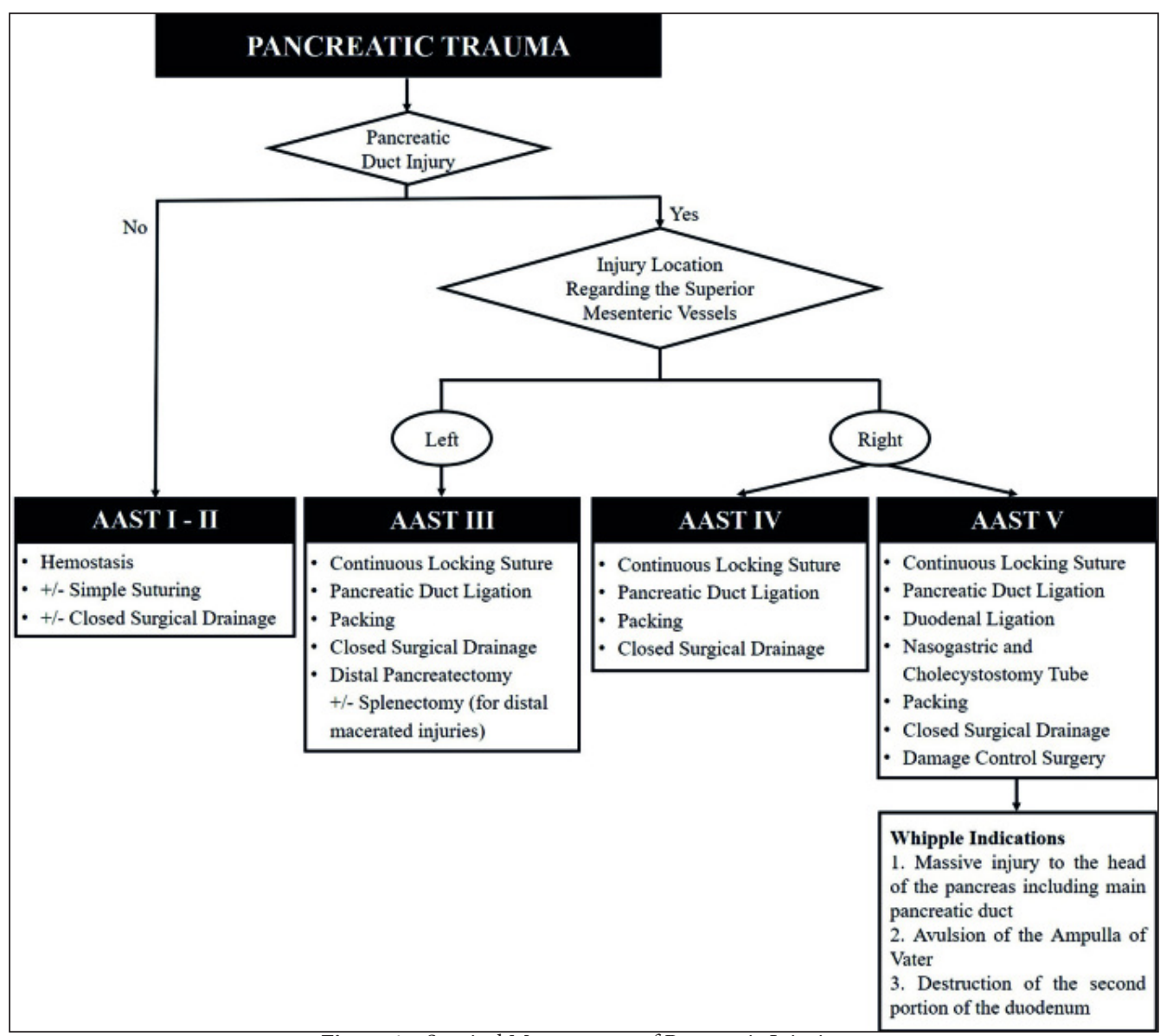

Figure 1. Surgical Management of Pancreatic Injuries

- $\quad$ AAST Grade III: hemostasis, distal pancreatectomy +/- splenectomy for injuries of the distal tail of the pancreas with significant tissue destruction, for all other injuries perform a continuous locking non-absorbable monofilament 3-0 suture of the transected borders of the lacerated pancreas, ligate both the proximal and distal ends of the transected pancreatic duct and surgical drainage. It is to note, that in all simple to moderate pancreatic injuries (Grade I-III) may require the implementation of DCS to manage any other significant associated vascular, hollow viscous and/or solid organ injury (Figures 3 and 4$)$

- AAST Grade IV: hemostasis by performing a continuous locking non-absorbable monofilament 3-0 suture of the transected borders of the lacerated pancreas, ligate both the proximal and distal ends of the transected pancreatic duct, pack the pancreas and complete your damage control procedure by leaving the abdomen open and placing a negative pressure dressing. In 24-48 hours, after the patient has been appropriately resuscitated and the lethal diamond has been corrected in the intensive care unit (ICU), then the patient is brought back to the OR for unpacking, abdominal washout and surgical drainage (Figure 5).

- $\quad$ AAST Grade V: please keep in mind that these patients are critically ill and with an extremely high mortality rate. DCS is a must ${ }^{18}$. The main goal is to isolate the pancreatic duodenal complex, performing a continuous locking non-absorbable monofilament 3-0 suture of the transected borders of the lacerated pancreas, ligate both the proximal and distal ends of the transected pancreatic duct, pack the pancreas, proximal control of duodenum by ligature of the first portion of the duodenum with a mechanical stapler, nasogastric and cholecystostomy tube placement to control gastric and biliary output and 


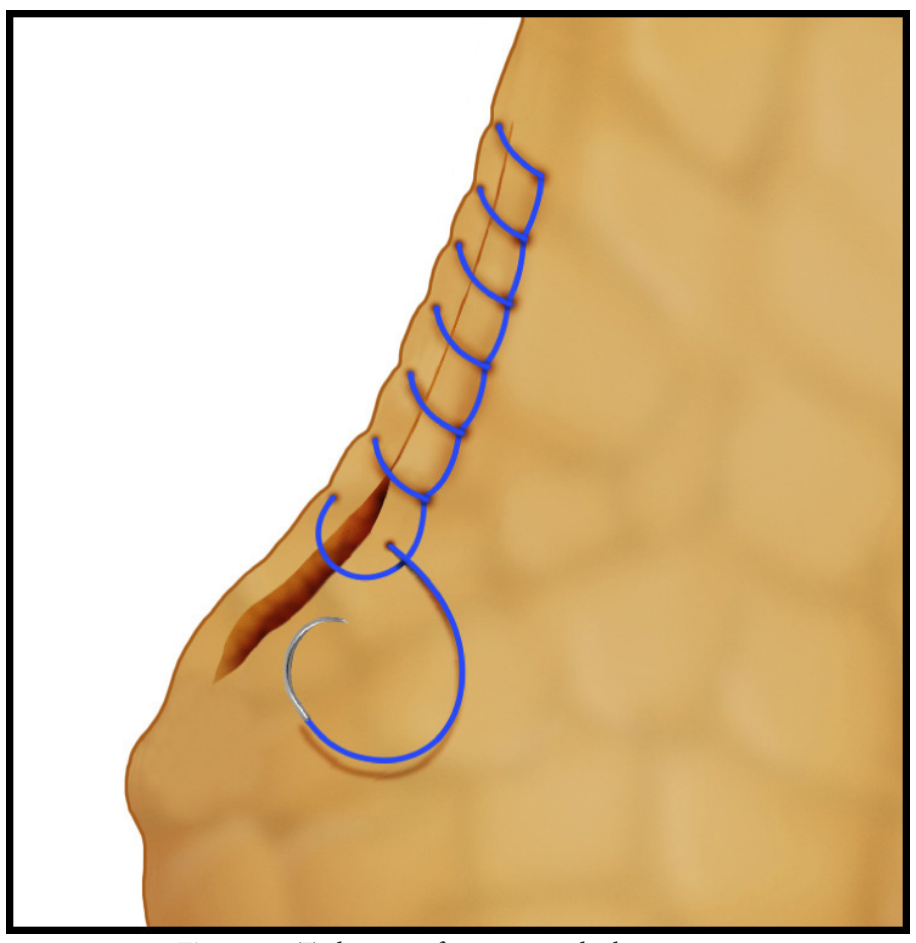

Figure 2. Technique of continuous locking suture

complete your damage control procedure by leaving the abdomen open, surgical closed drainage and placing a negative pressure dressing. In 24 to 48 hours, after the patient has been appropriately resuscitated and the lethal diamond has been corrected in the ICU, then the patient is brought back to the OR for unpacking, abdominal washout, possible pancreatic duodenectomy (Whipple Procedure) and closed surgical drainage ${ }^{6,19}$. The indications for a Whipple Procedure for trauma include: massive injury to the head of the pancreas including the main pancreatic duct, avulsion of the Ampulla of Vater and/or destruction of the second portion of the duodenum ${ }^{17}$. If these indications are not present then reassure control of all surgical bleeding and perform closed surgical drainage and definitive abdominal wall closure. If they are present, we recommend that you request assistance from a transplant and/or hepatobiliary surgeon to assist in the reconstruction of a Grade V injury which traditionally requires the re-establishment of bowel continuity, a biliary-enteric and a pancreatic-enteric anastomosis (Figure 6). The later, as the title of this manuscript implies, is in our experience: unnecessary, time consuming and prone to breakdown with significant subsequent complications.

\section{Complications}

The reported overall incidence of pancreatic fistula has been between 8 to $33 \%$ in patients that have undergone distal pancreatectomies for trauma ${ }^{11,20-22}$. That is why we propose the concept of suturing the parenchymal borders of the pancreatic injury to ensure hemostasis and decrease the overall incidence of pancreatic leak. It goes without saying that closed surgical drainage to any mayor injury is a must. Also, the parenchymal wound suturing of the injured pancreas preserves potentially healthy tissue that can, down the line, preserve the organs innate endocrine and exocrine functions. In our own experience, the use of pancreatic parenchymal sutures decreases the incidence of fistula ${ }^{12}$. If a pancreatic fistula does arise, closed drainage is the treatment of choice ${ }^{13}$. Most pancreatic fistulas are minor and selflimiting with closed drainage. Drains are removed when: the patient has returned to full enteral nutrition, the output of the drain is minimal and the amylase from the drain is equal or less than that of its value in serum. 

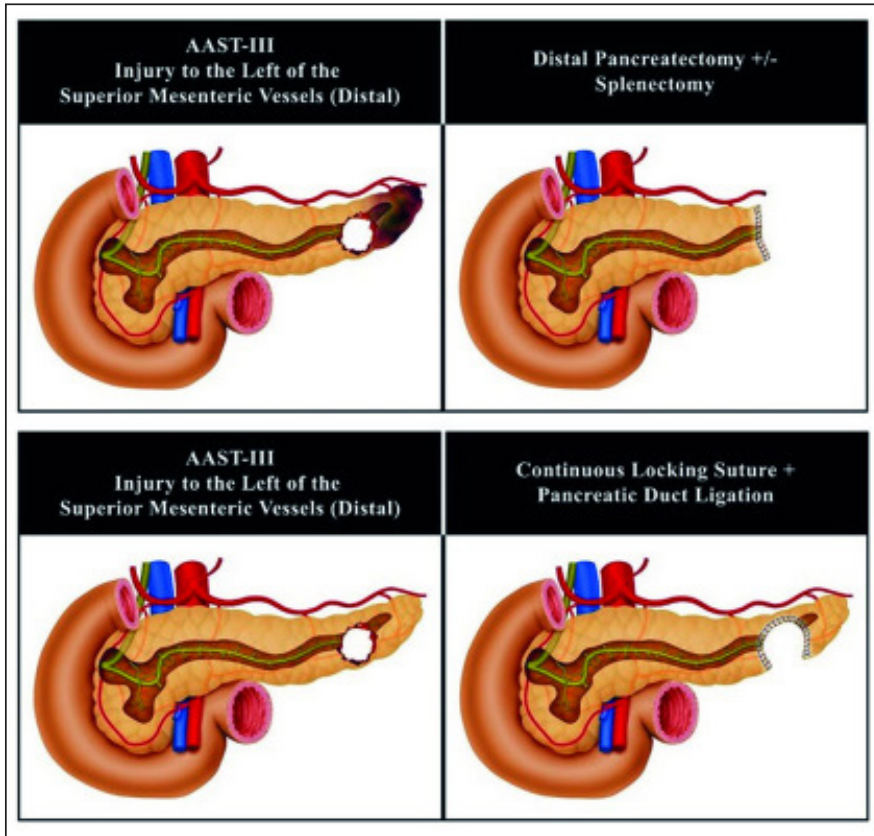

Figure 3. Surgical Management of Pancreatic Injury AAST-III to the Left of the Superior Mesenteric Vessels (Distal)

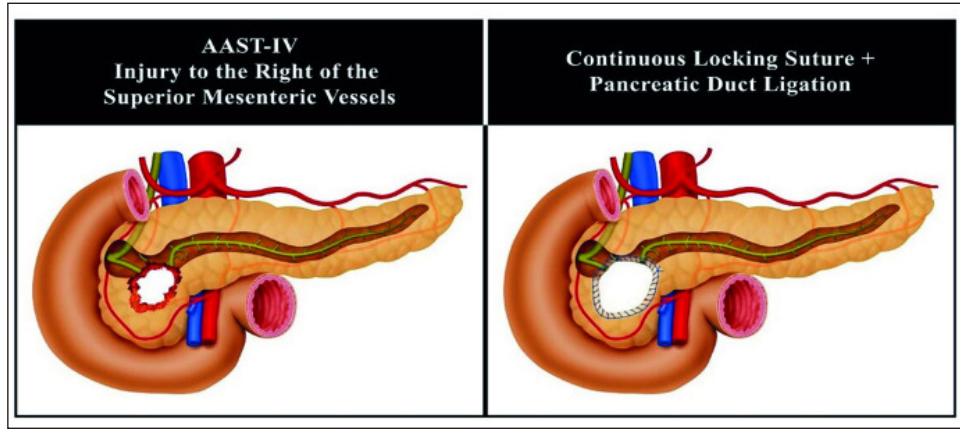

Figure 5. Surgical Management of Pancreatic Injury AAST-IV to the Right of the Superior Mesenteric Vessels (Proximal)
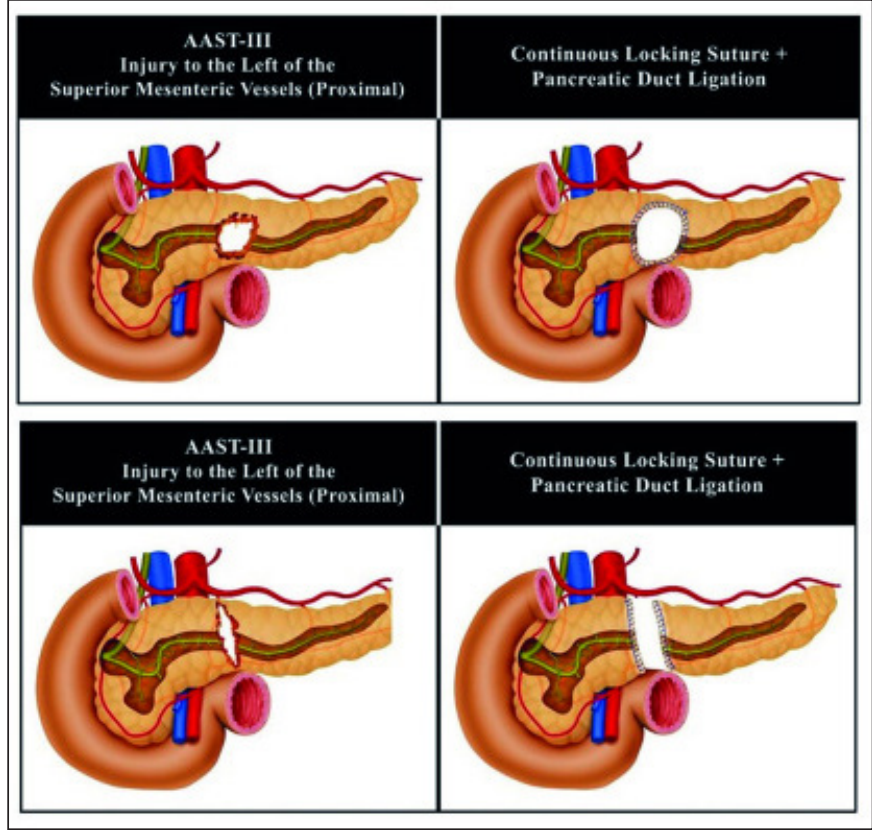

Figure 4. Surgical Management of Pancreatic Injury AAST-III to the Left of the Superior Mesenteric Vessels (Proximal)

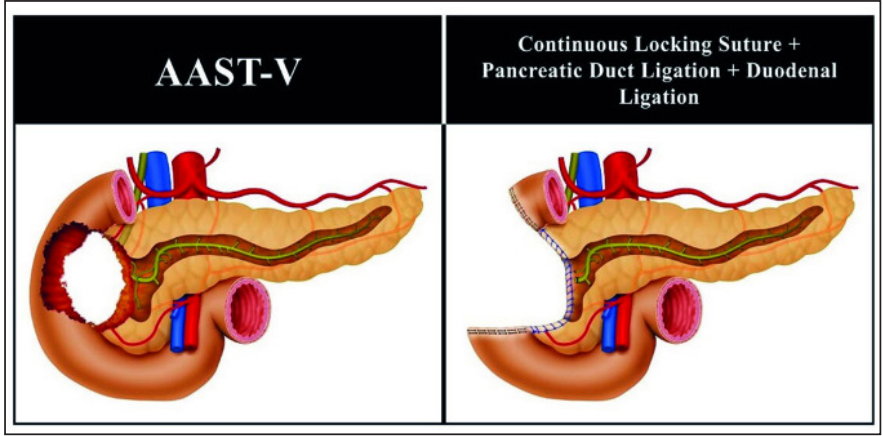

Figure 6. Surgical Management of Pancreatic Injury AAST-V

\section{Conclusion}

Most pancreatic injuries are AAST Grades I-III which can be managed with a combination of hemostatic maneuvers, pancreatic packing, parenchymal wound suturing and closed surgical drainage. Distal pancreatectomies +/- splenectomies with the inevitable loss of significant amounts of healthy pancreatic tissue must be avoided whenever possible. General principles of DCS must be applied when necessary followed by definitive surgical management when and only when appropriate physiological stabilization of the patient in the ICU has been achieved ${ }^{23,24}$. The general surgical approach to pancreatic injuries to date has been the performance of pancreatic tissue resections for moderate injuries and complex pancreaticenteric anastomosis in severe cases. It is our experience that viable un-injured pancreatic tissue should be left alone when possible in all types of pancreatic injuries (simple, moderate or complex) accompanied by adequate closed surgical drainage with the aim of preserving primary organ function and decreasing short and long term morbidity. 


\section{References}

1. lacono C, Zicari M, Conci S, Valdegamberi A, De Angelis M, Pedrazzani C, et al. Management of pancreatic trauma: A pancreatic surgeon's point of view. Pancreatology. 2016; 16: 302-8. doi: 10.1016/j.pan.2015.12.004.

2. Wiik Larsen J, Søreide K. The worldwide variation in epidemiology of pancreatic injuries. Injury. 2019; 50: 1787-9. doi: 10.1016/j.injury.2019.08.010.

3. Coccolini F, Kobayashi L, Kluger Y, Moore EE, Ansaloni L, Biffl W, et al. Duodeno-pancreatic and extrahepatic biliary tree trauma: WSES-AAST guidelines. World J Emerg Surg. 2019; 14: 56. doi: 10.1186/s13017-019-0278-6

4. Ahmed N, Vernick JJ. Pancreatic injury. South Med J. 2009; 102: 1253-6. doi: 10.1097/

SMJ.0b013e3181c0dfca.

5. Vasquez M, Cardarelli C, Glaser J, Murthi S, Stein D, Scalea T. The ABC's of pancreatic trauma: airway, breathing, and computerized tomography scan? Mil Med. 2017; 182: 66-71. doi: 10.7205/milmed-d-16-00084.

6. Krige JEJ, Kotze UK, Setshedi M, Nicol AJ, Navsaria PH. Management of pancreatic injuries during damage control surgery: an observational outcomes analysis of 79 patients treated at an academic Level 1 trauma centre. Eur J Trauma Emerg Surg. 2017; 43: 411-20. doi: 10.1007/s00068-016-0657-6.

7. Petrone P, Moral Álvarez S, González Pérez M, Ceballos Esparragón J, Marini CP. Traumatismos de páncreas: manejo y revisión de la literatura. Cir Esp. 2017; 95: 123-30. doi: 10.1016/j.ciresp.2016.05.011.

8. Jurkovich GJ. Pancreatic trauma. J Trauma Acute Care Surg. 2020; 88: 19-24. doi: 10.1097/

TA.0000000000002546.

9. Sharpe JP, Magnotti LJ, Weinberg JA, Zarzaur BL, Stickley SM, Scott SE, et al. Impact of a defined management algorithm on outcome after traumatic pancreatic injury. J. Trauma Acute Care Surg. 2012; 72: 100-5. doi: 10.1097/TA.0b013e318241f09d.

10. Shibahashi K, Sugiyama K, Kuwahara Y, Ishida T, Okura Y, Hamabe Y. Epidemiological state, predictive model for mortality, and optimal management strategy for pancreatic injury: A multicentre nationwide cohort study. Injury. 2020; 51: 59-65. doi: 10.1016/j.injury.2019.08.009.

11. Panda A, Kumar A, Gamanagatti S, Bhalla AS, Sharma R, Kumar S, et al. Evaluation of diagnostic utility of multidetector computed tomography and magnetic resonance imaging in blunt pancreatic trauma: A prospective study. Acta Radiol. 2015; 56: 387-96. doi: 10.1177/0284185114529949.

12. Rodriguez F, García A, Ordoñez C, Vernaza C, Herrera JP, Puyana JC. Trauma Pancreático Penetrante Severo-Revisión Retrospectiva de Una Serie de Casos Manejados Con Una Estrategia Simplificada en un Centro de Trauma Nivel 1. Panam J Trauma. 2015; 4: 147-54. doi: 10.5005/jp-journals-10030-1129.

13. Potoka DA, Gaines BA, Leppäniemi A, Peitzman AB. Management of blunt pancreatic trauma: what's new? Eur J Trauma Emerg Surg. 2015; 41: 239-50. doi: 10.1007/s00068-015-0510-3.

14. Schellenberg M, Inaba K, Bardes JM, Cheng V, Matsushima K, Lam L, et al. Detection of traumatic pancreatic duct disruption in the modern era. Am J Surg. 2018; 216: 299-303. doi: 10.1016/j. amjsurg.2018.06.002.

15. Osborn LA, Brenner ML, Prater SJ, Moore LJ. Resuscitative endovascular balloon occlusion of the aorta: Current evidence. Open Access Emerg Med. 2019; 11: 29-38. doi: 10.2147/OAEM.S166087.

16. Ordoñez CA, Parra M, Caicedo Y, Padilla N, Rodriguez F, Serna JJ, et al. REBOA as a New Damage Control Component in Hemodynamically Unstable NTCH patients. Colomb Med (Cali). 2020; 51(4): e204506. 
17. Girard E, Abba J, Arvieux C, Trilling B, Sage PY, Mougin N, et al. Management of pancreatic trauma. J Visc Surg. 2016; 153: 259-68. doi: 10.1016/j.jviscsurg.2016.02.006.

18. de Carvalho MEAJ, Cunha AG. Pancreaticodudonectomy in trauma: One or two stages? Injury. 2020; 51 : 592-6. doi: 10.1016/j.injury.2020.01.018.

19. Krige J, Nicol A, Navsaria P. Treating complex pancreatic injuries. Trauma and pancreatic surgeons working together is the modern management paradigm. J Visc Surg. 2017; 154: 143. doi: 10.1016/j. jviscsurg.2017.02.002.

20. Byrge N, Heilbrun M, Winkler N, Sommers D, Evans H, Cattin LM, et al. An AAST-MITC analysis of pancreatic trauma: Staple or sew? Resect or drain? J Trauma Acute Care Surg. 2018; 85(3): 435-443. doi: 10.1097/TA.0000000000001987.

21. Asensio JA, Petrone P, Roldán G, Kuncir E, Demetriades D. Pancreaticoduodenectomy: A rare procedure for the management of complex pancreaticoduodenal injuries. J Am Coll Surg. 2003; 197(6):937-42. doi: 10.1016/j.jamcollsurg.2003.07.019.

22. Vasquez JC, Coimbra R, Hoyt DB, Fortlage D. Management of penetrating pancreatic trauma: An 11-year experience of a level-1 trauma center. Injury. 2001; 32(10): 753-9. doi: 10.1016/S0020-1383(01)00099-7.

23. Ball CG, Correa-Gallego C, Howard TJ, Zyromski NJ, Lillemoe KD. Damage Control Principles for Pancreatic Surgery. J Gastrointest Surg. 2010; 14: 1632-3. doi: 10.1007/s11605-010-1286-8.

24. Ordoñez CA, Badiel M, Pino LF, Salamea JC, Loaiza JH, Parra MW, et al. Damage control resuscitation: Early decision strategies in abdominal gunshot wounds using an easy "aBCD" mnemonic. J Trauma Acute Care Surg. 2012; 73:1074-8. doi: 10.1097/TA.0b013e31826fc780.

25. Moore E, Cogbill T, Malangoni M, Jurkovich G, Champion H, Gennarelli T, et al. Organ injury scaling, II: pancreas, duodenum, small bowel, colon and rectum. J Trauma. 1990; 30: 1427-9. 